\title{
Pension Accounting And Reporting With Other Comprehensive Income And Deferred Taxes: A Worksheet Approach
}

Robert E. Jackson, Ph.D., Georgia Southern University, USA

L. Dwight Sneathen Jr., Ph.D., Georgia Southern University, USA

Timothy R. Veal, Partner - Nichols, Cauley, \& Associates, Dublin, Georgia, USA

\begin{abstract}
This instructional tool presents pension accounting using a worksheet approach where debits equal credits for both the employer and for the plan. Transactions associated with the initiation of the plan through the end of the second year of the plan are presented, including their impact on accumulated other comprehensive income and deferred taxes. This article is intended as a supplemental teaching tool that demonstrates the impact of a plan's funded status on the employer's financial statements in a way that, based upon anecdotal evidence, accounting students and practitioners have found extremely beneficial beyond traditional accounting textbooks.
\end{abstract}

Keywords: Pension Reporting; Other Comprehensive Income; Deferred Income Taxes; FASB ASC No. 220, FASB ASC No. 715

\section{INTRODUCTION}

Cccounting educators are tasked with conveying complex topics, such as defined benefit pension plans, in a manner that students can assimilate in the classroom. Unfortunately, the true complexities of these topics may be lost in the simplified scenarios presented in traditional textbooks. Traditional textbooks ${ }^{1}$ typically present the accounting for pensions in isolation, lacking a comprehensive discussion of the impact of pension plans on the recognition of deferred income taxes, and the presentation of other comprehensive income. Accounting educators need a tool that will bring these otherwise separate topics together, and allow students to see this topic in its entirety.

We find a worksheet approach useful in teaching the underlying accounting processes and disclosure requirements of single-employer defined benefit pension plans. Where textbooks present an unbalanced set of information for the plan side of the pension, we can balance the plan side of the worksheet by including a 'Due from (Due to) Employer' column. This simple adjustment facilitates reconciliation of the plan side of the pension, and allows students to utilize a foundational tenant of accounting. Using the worksheet, one can readily see the how the periodic pension transactions affect the funded status of the plan, and more comprehensively illustrates changes in additional reporting information related to deferred taxes and other comprehensive income.

Students utilizing this methodology in the classroom have found it useful when confronted with pension accounting issues in subsequent coursework, and in practice. A prior student, and audit manager, successfully used this presentation during audit planning to prepare his audit team for a client engagement that included a defined benefit pension plan.

\footnotetext{
${ }^{1}$ For examples, see Kieso, Weygandt, and Warfield, Intermediate Accounting, and Spiceland, Sepe, Nelson, and Tomassini, Intermediate Accounting.
} 
This paper presents the transactions and worksheet from initiation of the plan through the second year of a plan. Required disclosures and Comprehensive Income presentation are summarized for the two years.

\section{THE WORKSHEET}

Textbook presentation of pension accounting focuses on the employer side of the pension plan, providing plan side figures as they apply to employer reporting such as the projected benefit obligation (PBO) and plan assets. We have adapted the employer side to encompass the new reporting requirements of SFAS 158 and Comprehensive Income (Topic 220), and we have developed a means of balancing the plan side of the worksheet as well as the employer side of the worksheet.

This worksheet, similar to most, has sections for both the employer (plan sponsor) and the plan. The employer's portion of the worksheet includes traditional columns for pension expense, cash, and the accrued pension liability. To fulfill the reporting requirements of FASB ASC 715 we have included the non-current pension liability, accumulated other comprehensive income (OCI), and deferred taxes. The plan portion of the worksheet includes the projected benefit obligation (PBO), plan assets, and a receivable from the employer. The inclusion of the receivable from employer column allows both the plan and employer sides of the worksheet to balance; debits equal credits.

The due from (due to) employer represents the cumulative obligation from the employer, corresponding to the combination of the Prepaid (Accrued) Pension Expense and the Noncurrent Portion - Pension Asset (Liability). The deferred taxes will be computed at the reporting date, and treated as a reversing entry. This will clearly provide totals for the gross and net of tax figures required by the amendments to comprehensive income reporting in FASB ASC 220.

\section{Plan adoption and first year worksheet activity}

The actuarial report for the first year of the plan is provided below. It shows the PBO at plan adoption, pension expense incurred during the year, and contributions to the plan.

\begin{tabular}{l|ccc} 
& Projected Benefit Obligation & Plan Assets & Pension Expense \\
\hline Plan adoption & $\$(100,000)$ & & \\
Service Costs & $(15,000)$ & & $\$ 15,000$ \\
Interest Costs & $(8,000)$ & & 8,000 \\
Amortization of prior service costs & & $\$ 30,000$ & 10,000 \\
Employer contribution & $\underline{\underline{\$(123,000)}}$ & $\underline{\underline{\$ 30,000}}$ & $\underline{\$ 33,000}$
\end{tabular}

The expected return on assets and interest costs are $8 \%$ and the average service life of plan participants is 10 years. The employer's side of the worksheet below reflects these transactions.

\begin{tabular}{|c|c|c|c|c|c|c|c|}
\hline Date & Description & $\begin{array}{c}\text { Unrecognized } \\
\text { Prior Service } \\
\text { Costs (OCI) }\end{array}$ & $\begin{array}{c}\text { Deferred } \\
\text { Income Tax }\end{array}$ & $\begin{array}{c}\text { Noncurrent } \\
\text { portion- } \\
\text { Pension } \\
\text { Asset } \\
\text { (Liability) }\end{array}$ & $\begin{array}{l}\text { Pension } \\
\text { Expense }\end{array}$ & Cash & $\begin{array}{c}\text { Prepaid } \\
\text { (Accrued) } \\
\text { Pension } \\
\text { Expense }\end{array}$ \\
\hline $1 / 1 / x 1$ & Plan Adoption & $\$ 100,000$ & & $\$(100,000)$ & & & \\
\hline $12 / 31 / x 1$ & Service Costs & & & & $\$ 15,000$ & & $\$(15,000)$ \\
\hline $12 / 31 / x 1$ & Interest Costs & & & & 8,000 & & $(8,000)$ \\
\hline $12 / 31 / x 1$ & Amortization of PSC & $(10,000)$ & & 10,000 & 10,000 & & $(10,000)$ \\
\hline $12 / 31 / x 1$ & Employer Contribution & & & & & $\$(30,000)$ & 30,000 \\
\hline $12 / 31 / x 1$ & Year-end Balances & $\$ 90,000$ & & $\$(90,000)$ & $\$ 33,000$ & $\$(30,000)$ & $\$(3,000)$ \\
\hline
\end{tabular}


The plan side of the worksheet below reflects these transactions.

\begin{tabular}{llccc}
\multicolumn{1}{c}{ Date } & \multicolumn{1}{c}{ Description } & $\begin{array}{c}\text { Due From (Due To) } \\
\text { Employer }\end{array}$ & $\begin{array}{c}\text { Projected Benefit } \\
\text { Obligation }\end{array}$ & Plan Assets \\
\hline $1 / 1 / \mathrm{x} 1$ & Plan Adoption & $\$ 100,000$ & $\$(100,000)$ & \\
$12 / 31 / \mathrm{x} 1$ & Service Costs & 15,000 & $(15,000)$ & \\
$12 / 31 / \mathrm{x} 1$ & Interest Costs & 8,000 & & \\
$12 / 31 / \mathrm{x} 1$ & Amortization of PSC & & & $30,000)$ \\
$12 / 31 / \mathrm{x} 1$ & Employer Contribution & $(30,000)$ & $\$(123,000)$ & $\$ 30,000$
\end{tabular}

As presented above the plan is adopted resulting in the recognition of the original benefit obligation of $\$ 100,000$ on the employer and plan side of the worksheet. Service costs are included as given, and Interest costs are computed using the 8\% expected return. At the year end the Unrecognized Prior Service Cost is amortized, and employer contributions recognized. The year-end total for Due From Employer is equal to the funded status of the plan, and reconciles with the pension liabilities reflected on the employer's side of the worksheet (Noncurrent portion - Pension Liability and Accrued Pension Expense).

Finally, using the information in the worksheet the employer can use the non-current pension asset (liability) to determine the related deferred tax (liability) asset. The deferred taxes should be allocated to the other comprehensive income components arising from pension plan activity. The worksheet below shows the components of other comprehensive income, net of taxes, which should be reflected in the equity section of employer's balance sheet. We use a future tax rate of $35 \%$. The changes to other comprehensive income, net of taxes, are the components of the current year, comprehensive income that should be presented in the Statement of Comprehensive Income.

\begin{tabular}{|c|c|c|c|c|c|c|c|}
\hline Date & Description & $\begin{array}{c}\text { Unrecognized } \\
\text { Prior Service } \\
\text { Costs (OCI) }\end{array}$ & $\begin{array}{c}\text { Deferred } \\
\text { Income Tax }\end{array}$ & $\begin{array}{c}\text { Noncurrent } \\
\text { portion- } \\
\text { Pension } \\
\text { Asset } \\
\text { (Liability) }\end{array}$ & $\begin{array}{l}\text { Pension } \\
\text { Expense }\end{array}$ & Cash & $\begin{array}{c}\text { Prepaid } \\
\text { (Accrued) } \\
\text { Pension } \\
\text { Expense }\end{array}$ \\
\hline $1 / 1 / \mathrm{x} 1$ & Plan Adoption & $\$ 100,000$ & & $\$(100,000)$ & & & \\
\hline $12 / 31 / \times 1$ & Service Costs & & & & $\$ 15,000$ & & $\$(15,000)$ \\
\hline $12 / 31 / \mathrm{x} 1$ & Interest Costs & & & & 8,000 & & $(8,000)$ \\
\hline $12 / 31 / x 1$ & Amortization of PSC & $(10,000)$ & & 10,000 & 10,000 & & $(10,000)$ \\
\hline $12 / 31 / \mathrm{x} 1$ & Employer Contribution & & & & & $\$(30,000)$ & 30,000 \\
\hline \multirow[t]{2}{*}{$12 / 31 / x 1$} & $\begin{array}{l}\text { Year-end Balances } \\
\text { Deferred Income Tax }\end{array}$ & $\begin{array}{l}\$ 90,000 \\
(31,500)\end{array}$ & 31,500 & $\$(90,000)$ & $\$ 33,000$ & $\$(30,000)$ & $\$(3,000)$ \\
\hline & After Tax Amounts & $\$ 58,500$ & $\$ 31,500$ & $\$(90,000)$ & $\$ 33,000$ & $\$(30,000)$ & $\$(3,000)$ \\
\hline
\end{tabular}

\section{Second year worksheet activity}

The actuarial report for the second year follows.

\begin{tabular}{|c|c|c|c|}
\hline & Projected Benefit Obligation & Plan Assets & Pension Expense \\
\hline Beginning Balances & $\$(123,000)$ & $\$ 30,000$ & \\
\hline Service Costs & $(18,000)$ & & $\$ 18,000$ \\
\hline Interest Costs & $(9,840)$ & & 9,840 \\
\hline Amortization of prior service costs & & & 10,000 \\
\hline Earnings on Plan Assets & & 3,200 & $(2,400)$ \\
\hline Employer contribution & & $\$ 40,000$ & \\
\hline Benefits Paid & 1,000 & $(1,000)$ & \\
\hline Ending Balances & $\underline{\underline{\$(149,840)}}$ & $\underline{\$ 72,200}$ & $\underline{\$ 35,440}$ \\
\hline
\end{tabular}


The worksheet reflecting this activity follows.

\begin{tabular}{|c|c|c|c|c|c|c|c|c|}
\hline Date & Description & $\begin{array}{c}\text { Unrecognized } \\
\text { Prior Service } \\
\text { Costs }(\text { OCI) }\end{array}$ & $\begin{array}{l}\text { Unrecognized } \\
\text { (Gain) Loss } \\
\text { (OCI) }\end{array}$ & $\begin{array}{c}\text { Deferred } \\
\text { Income } \\
\text { Tax }\end{array}$ & $\begin{array}{c}\text { Noncurrent } \\
\text { portion- } \\
\text { Pension } \\
\text { Asset } \\
\text { (Liability) }\end{array}$ & $\begin{array}{c}\text { Pension } \\
\text { Expense }\end{array}$ & Cash & $\begin{array}{c}\text { Prepaid } \\
\text { (Accrued) } \\
\text { Pension } \\
\text { Expense }\end{array}$ \\
\hline $12 / 31 / x 1$ & $\begin{array}{l}\text { After Tax } \\
\text { Amounts }\end{array}$ & $\$ 58,500$ & & $\$ 31,500$ & $\$(90,000)$ & $\$ 33,000$ & $\$(30,000)$ & $\$(3,000)$ \\
\hline $1 / 1 / x 2$ & $\begin{array}{l}\text { Reverse } \\
\text { Deferred Tax }\end{array}$ & 31,500 & & $(31,500)$ & & & & \\
\hline $12 / 31 / x 2$ & Service Costs & & & & & $\$ 18,000$ & & $\$(18,000)$ \\
\hline $12 / 31 / x 2$ & Interest Costs & & & & & 9,840 & & $(9,840)$ \\
\hline $12 / 31 / x 2$ & $\begin{array}{l}\text { Amortization of } \\
\text { PSC }\end{array}$ & $(10,000)$ & & & 10,000 & 10,000 & & $(10,000)$ \\
\hline $12 / 31 / x 2$ & $\begin{array}{l}\text { Return on Plan } \\
\text { Assets }\end{array}$ & & $\$(800)$ & & 800 & $(2,400)$ & & 2,400 \\
\hline $12 / 31 / x 2$ & $\begin{array}{l}\text { Employer } \\
\text { Contribution }\end{array}$ & & & & & & $\$(40,000)$ & 40,000 \\
\hline \multirow[t]{2}{*}{$12 / 31 / x 2$} & $\begin{array}{l}\text { Year-end } \\
\text { Balances } \\
\text { Deferred } \\
\text { Income Tax }\end{array}$ & $\begin{array}{l}\$ 80,000 \\
(28,000)\end{array}$ & 280 & 27,720 & $\$(79,200)$ & $\$ 35,440$ & $\$(40,000)$ & $\$ 1,560$ \\
\hline & $\begin{array}{l}\text { After Tax } \\
\text { Amounts }\end{array}$ & $\$ 52,000$ & $\$(520)$ & $\$ 27,720$ & $\$(79,200)$ & $\$ 35,440$ & $\$(40,000)$ & $\$ 1,560$ \\
\hline
\end{tabular}

\begin{tabular}{llccc} 
Date & \multicolumn{1}{c}{ Description } & $\begin{array}{c}\text { Due From (Due To) } \\
\text { Employer }\end{array}$ & $\begin{array}{c}\text { Projected Benefit } \\
\text { Obligation }\end{array}$ & Plan Assets \\
\hline $12 / 31 / \mathrm{x} 1$ & Year-end Balances & $\$ 93,000$ & $\$(123,000)$ & $\$ 30,000$ \\
$12 / 31 / \mathrm{x} 2$ & Service Costs & 18,000 & $(18,000)$ & \\
$12 / 31 / \mathrm{x} 2$ & Interest Costs & 9,840 & & \\
$12 / 31 / \mathrm{x} 2$ & Amortization of PSC & $(3,200)$ & & 3,200 \\
$12 / 31 / \mathrm{x} 2$ & Return on Plan Assets & & 1,000 & $(1,000)$ \\
$12 / 31 / \mathrm{x} 2$ & Benefits Paid & $(40,000)$ & & 40,000 \\
$12 / 31 / \mathrm{x} 2$ & Employer Contribution & $\$ 77,640$ & $\$(149,840)$ & $\$ 72,200$
\end{tabular}

As presented above we start the year by reversing the deferred taxes from year X1. Service costs are given, and the Interest costs are computed by multiplying the ending balance in the PBO from X1 by the expected return of $8 \%$. The Unrecognized Prior Service Cost is amortized, and employer contributions are recognized. In year X2, the return on plan assets exceeds the expected return. Pension Expense captures the expected return on plan assets, while the excess is captured in Other Comprehensive Income (OCI) column labeled 'Unrecognized Gain'. The deferral of the unrecognized (gain) loss demonstrates how the employer achieves income smoothing through accounting for pension expense.

Again, the calculation of deferred tax asset (liability) related to the components of other comprehensive income must be made at the end of the year. The net changes to other comprehensive income, net of taxes, are the components of the current year comprehensive income related to pension expense.

\section{DISCLOSURE}

The amounts presented in the worksheet are direct inputs into the financial statements. The balance sheet accounts include the Noncurrent portion - Pension Liability, Prepaid (Accrued) Pension Expense, and the AOCI items (Unrecognized Prior Service Cost and Unrecognized (Gain) Loss) which are presented net of deferred taxes. The amounts would be presented as follows: 
Reporting Year

Current Assets - Prepaid Pension Expense

Noncurrent Assets - Deferred Taxes

Current Liabilities - Accrued Pension Expense

Noncurrent Liabilities - Pension Liability

Equity - Accumulated OCI

$\begin{array}{cc}\mathrm{X} 1 & \mathrm{X} 2 \\ \mathrm{DR}(\mathrm{CR}) & \mathrm{DR}(\mathrm{CR}) \\ 31,500 & 1,560 \\ (3,000) & 27,720 \\ (90,000) & \\ 58,500 & (79,200) \\ & 51,480\end{array}$

The Statement of Comprehensive Income would capture current period changes in the OCI accounts. These amounts can be presented in a single statement below Net Income, or is a separate statement immediately following the Statement of Income. OCI amounts can be presented net of tax, or at their gross amount with an aggregate tax expense of benefit.

These examples present the items of comprehensive income beginning with net income. The first presents numbers before tax and provides a summary of the impact of income tax. The second presents the numbers net of $\operatorname{tax}$.

Reporting Year

Net Income

Other Comprehensive Income, before tax:

Defined Benefit Pension Plans:

Prior Service Cost arising from plan adoption

Net income arising during period

Less: amortization of prior service cost

Included in net periodic pension cost

Other Comprehensive Income, before tax

Income tax related to items of other comprehensive income

Other Comprehensive Income, net of tax

Comprehensive Income

Reporting Year

Net Income

Other Comprehensive Income, net of tax:

Defined Benefit Pension Plans:

Prior Service Cost arising from plan adoption

Net income arising during period

Less: amortization of prior service cost

Included in net periodic pension cost

Other Comprehensive Income, net of tax

Comprehensive Income

\begin{tabular}{|c|c|}
\hline $\mathrm{X} 1$ & $\mathrm{X} 2$ \\
\hline$\$$ & $\$$ \\
\hline \multicolumn{2}{|l|}{$(100,000)$} \\
\hline 10,000 & 10,000 \\
\hline$(90,000)$ & 10,800 \\
\hline 31,500 & $(3,780)$ \\
\hline$(58500)$ & 7,020 \\
\hline$\$$ & $\$$ \\
\hline $\mathrm{X} 1$ & $\mathrm{X} 2$ \\
\hline$\$$ & $\$$ \\
\hline$(65,000)$ & 520 \\
\hline 6,500 & 6,500 \\
\hline$(58,500)$ & 7,020 \\
\hline$\$$ & $\$$ \\
\hline
\end{tabular}

The before tax presentation allows the user to draw the information directly from the worksheet, as presented in this paper. The after tax presentation can be accommodated by inserting additional columns for each transaction within the pension related other comprehensive income accounts. For example, separate columns could be used to account for plan adoption/amendment and amortization of unrecognized prior service cost as well as columns for actuarial gains (losses), unrecognized gains (losses) arising from the difference between actual and expected returns on plan assets, and amortization of the unrecognized gains (losses).

Summary

\section{CONCLUSION}

Using a worksheet approach allows the students to utilize their knowledge of basic accounting entries and that debits must equal credits to generate the information needed to properly account for pensions under FASB ASC 715. The worksheet also makes it easier for students to see the components of other comprehensive income that arise from pension transactions as well as the related deferred tax amounts. Additionally, students see when the 
components of other comprehensive income enter the earnings stream. Once the student understands accounting for pensions, it will be much easier to transition to the accounting for other post-employment benefit plans.

\section{AUTHOR INFORMATION}

Robert E. Jackson is a CPA and an Assistant Professor of Accounting at Georgia Southern University, Statesboro, Georgia USA. Prior to entering academia, he spent over twenty years in the practice of public accountancy in Florida. His research interests include corporate governance, corporate finance, and professional regulation. E-mail: rjackson@georgiasouthern.edu

L. Dwight Sneathen Jr. is a CPA and an Associate Professor of Accounting at Georgia Southern University, Statesboro, Georgia USA. He has experience in public accounting and private industry prior to entering academia. His research interests include topics in capital markets and auditing. E-mail: dsneathen@georgiasouthern.edu (Corresponding author)

Timothy R. Veal is a CPA and Partner with Nichols Cauley \& Associates in Dublin, Georgia USA. He has been with the firm for twenty five years, and has been a Partner for thirteen years. He has a diverse background of audit, tax and business consulting with specific experience in industries such as Financial Institutions, Construction, and Government Entities. E-mail: tveal@nicholscauley.com

\section{REFERENCES}

1. Financial Accounting Standards Board. (2011). FASB ASC 715 -Compensation-Retirement Benefits. Stamford, CT: Financial Accounting Standards Board.

2. Financial Accounting Standards Board. (2011). FASB ASC 220 - Comprehensive Income. Stamford, CT: Financial Accounting Standards Board.

3. Kieso, D. E., Weygandt, J. J., and Warfield, T. D. (2012). Intermediate Accounting, $14^{\text {th }}$ edition. New Jersey: John Wiley \& Sons, Inc. Hoboken.

4. Spiceland, J. D., Sepe, J. F., Nelson, M. W., and Tomassini, L. A. (2011). Intermediate Accounting, $6^{\text {th }}$ edition. New York: McGraw-Hill Companies, Inc. New York. 


\section{APPENDIX A}

Journal entries for year 20X1:

Accrued Pension Expense $\quad 30,000$

Cash

30,000

To record employer contribution to pension plan during 20X1

Pension Expense

Accrued Pension Expense

To record pension expense for the 20X1

Other comprehensive income - Unrecognized PSC

Deferred Income Taxes

31,500

Pension Liability - non-current

90,000

To record change in Other Comprehensive Income net of related deferred taxes, the related deferred taxes, and the change in the non-current liability during the current year

After recording these entries, the general ledger will reflect the amounts shown in the worksheet for 20X1.

Journal entries for 20X2:

Accrued Pension Expense

Cash

40,000

To record employer contribution to pension plan during 20X2

Pension Expense

Accrued Pension Expense

To record pension expense for the $20 \mathrm{X} 2$

Pension Liability - non-current

10,800

Other comprehensive income - Unrecognized PSC

Other comprehensive income - Unrecognized (Gain) Loss

Deferred Income Taxes

3,780

To record adjustments to Other Comprehensive Income net of related deferred taxes, the related deferred taxes, and the change in the non-current liability during the current year

After recording these entries, the general ledger will reflect the amounts shown in the worksheet for 20X2. 
NOTES 